\title{
Greenhouse Gas and Ammonia Emissions from Different Stages of Liquid Manure Management Chains: Abatement Options and Emission Interactions
}

\author{
Erangu Purath Mohankumar Sajeev, * Wilfried Winiwarter, and Barbara Amon
}

\begin{abstract}
Farm livestock manure is an important source of ammonia and greenhouse gases. Concerns over the environmental impact of emissions from manure management have resulted in research efforts focusing on emission abatement. However, questions regarding the successful abatement of manure-related emissions remain. This study uses a meta-analytical approach comprising 89 peer-reviewed studies to quantify emission reduction potentials of abatement options for liquid manure management chains from cattle and pigs. Analyses of emission reductions highlight the importance of accounting for interactions between emissions. Only three out of the eight abatement options considered (frequent removal of manure, anaerobic digesters, and manure acidification) reduced ammonia (3-60\%), nitrous oxide ( $21-55 \%)$, and methane (29-74\%) emissions simultaneously, whereas in all other cases, tradeoffs were identified. The results demonstrate that a shift from single-stage emission abatement options towards a wholechain perspective is vital in reducing overall emissions along the manure management chain. The study also identifies some key elements like proper clustering, reporting of influencing factors, and explicitly describing assumptions associated with abatement options that can reduce variability in emission reduction estimates. Prioritization of abatement options according to their functioning can help to determine low-risk emission reduction options, specifically options that alter manure characteristics (e.g., reduced protein diets, anaerobic digestion, or slurry acidification). These insights supported by comprehensive emission measurement studies can help improve the effectiveness of emission abatement and harmonize strategies aimed at reducing air pollution and climate change simultaneously.
\end{abstract}

\section{Core Ideas}

- Emission reductions of abatement options were quantified in the manure management chain.

- Significant emission interactions exist in manure management chains.

- Single-stage emission abatement needs to shift to a wholechain perspective.

- Understanding variability of results minimizes uncertainty of emission reductions.

- A holistic management strategy is required to tackle air pollution and climate change.

Copyright $\odot$ American Society of Agronomy, Crop Science Society of America, and Soil Science Society of America. 5585 Guilford Rd., Madison, WI 53711 USA.

All rights reserved.

J. Environ. Qual. 47:30-41 (2018)

doi:10.2134/jeq2017.05.0199

This is an open access article distributed under the terms of the CC BY license

(https://creativecommons.org/licenses/by/4.0/).

Supplemental material is available online for this article.

Received 22 May 2017.

Accepted 27 Oct. 2017

*Corresponding author (em.sajeev@uni-graz.at).

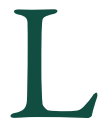

IVESTOCK production and rearing is a major source of ammonia $\left(\mathrm{NH}_{3}\right)$ and greenhouse gas (GHG) emissions. In 2014, the livestock sector contributed a share of $53 \%$ methane $\left(\mathrm{CH}_{4}\right), 21 \%$ nitrous oxide $\left(\mathrm{N}_{2} \mathrm{O}\right)$, and $75 \%$ $\mathrm{NH}_{3}$ to total agricultural emissions in the European Union (EU-28) (UNECE, 2016; UNFCCC, 2016). The negative impacts of these emissions on the environment have been widely reported. Accumulation of GHGs in the atmosphere causes climate change, which leads to undesirable consequences like sea level rise, increase in extreme weather events, and losses in food production (Stocker et al., 2013). Ammonia, on the other hand, poses a threat to terrestrial and aquatic systems and contributes to the formation of particulate matter in the atmosphere, which is harmful for human health (Sutton et al., 2011). Ammonia volatilization and subsequent atmospheric deposition is also a source of indirect $\mathrm{N}_{2} \mathrm{O}$ emissions (De Klein et al., 2006). Given the projected increase in demand for livestock products (Steinfeld et al., 2007), there is a pressing need to abate emissions from livestock.

Among the many sources associated with emissions from the livestock sector, emissions from manure management are prominent. Emissions from manure management include emissions from animal housing, during the handling and storage of manure, grazing, and the application of manure as a fertilizer to soils. Manure management alone accounts for $31 \%$ of GHGs and almost all of $\mathrm{NH}_{3}$ emissions from livestock in the EU-28 (UNECE, 2016; UNFCCC, 2016). Policies are in place to tackle emissions from manure management in EU-28. In terms of $\mathrm{NH}_{3}$, national policies reflect a response to obligations accepted with the Gothenburg Protocol under the Convention on Long-Range Transboundary Air Pollution, or the National Emission Ceilings Directive. Ammonia emissions are also affected by indirect policies that are not necessarily aimed at reducing $\mathrm{NH}_{3}$ but influence them, such as the Directive on Integrated Pollution Prevention and Control, the Common Agricultural Policy, the Nitrate Directive, and the Water Framework Directive. The Kyoto Protocol and the 20-20-20 targets under the Climate and Energy Package focus on reducing GHG emissions. The Common Agricultural Policy and Nitrate

E.P.M. Sajeev, Institute of System Sciences, Innovation and Sustainability Research (ISIS) and FWF-DK Climate Change, Univ. of Graz, Graz, Austria; W. Winiwarter, International Institute for Applied Systems Analysis (IIASA), Laxenburg, Austria, Institute of Environmental Engineering, Univ. of Zielona Góra, Zielona Góra, Poland; B. Amon, Leibniz Institute for Agricultural Engineering and Bioeconomy (ATB), Potsdam, Germany. Assigned to Associate Editor Heidi Waldrip.

Abbreviations: $\mathrm{CO}_{2}$ e, carbon dioxide equivalents; $\mathrm{CP}$, Crude protein; $\mathrm{EU}$, European Union; GHG, greenhouse gas. 
Directive also influence agricultural decisions and thereby affect emissions of GHGs. These policies are informed by scientific research, highlighting their role in regulating emissions from manure management.

Many studies have analyzed and evaluated the potential of abatement options to reduce $\mathrm{NH}_{3}$ and GHGs (Ivanova-Peneva et al., 2008; Sistani et al., 2010; Rodhe et al., 2012; Dai and Blanes-Vidal, 2013; Madrid et al., 2013). Although these studies are valuable in estimating the emission reduction potentials of abatement options, they do suffer from some drawbacks. The majority of literature focuses on the abatement of a single gas, be it $\mathrm{NH}_{3}$ or GHGs $\left(\mathrm{CH}_{4}\right.$ and $\mathrm{N}_{2} \mathrm{O}$ expressed in carbon dioxide equivalents $\left.\left[\mathrm{CO}_{2} \mathrm{e}\right]\right)$. This is problematic, since there are significant interactions between emissions and abatement options, whereby abating a single pollutant might lead to increases in the other (i.e., pollution swapping). Although, the idea of emission interactions and their effect on the ability of abatement strategies to reduce multiple pollutants has been discussed in literature (Brink et al., 2005; Anthony et al., 2008; Wagner et al., 2011; Winiwarter and Klimont, 2011; UNECE, 2015; Wagner et al., 2015), a systematic evaluation of emission interactions in the management of manure is still amiss. Second, abatement options are usually recommended for a single stage within the entire manure handling and management chain. Although this is important, it is often found lacking in a broader context, since reduction of emissions at one stage might lead to emissions further down the chain. Only a few studies address this issue. Such studies recommend a whole-chain or mass-flow approach in evaluating abatement strategies (Sommer et al., 2009; Chadwick et al., 2011; Del Prado et al., 2013). An analysis of literature related to emission abatement in manure management suggests that only some studies used a whole-chain approach inclusive of emission interactions (Gooday et al., 2014; De Vries et al., 2015; Hou et al., 2015, 2017; Wang et al., 2017).

The present study identifies potential abatement options to reduce GHGs and $\mathrm{NH}_{3}$ emissions collectively. It also sheds light on the potential cobenefits and the issue of pollution swapping by determining the trends in interactions of $\mathrm{CH}_{4}, \mathrm{~N}_{2} \mathrm{O}$, and $\mathrm{NH}_{3}$ among the various abatement options identified. The deficiencies in single-pollutant, single-stage approaches when devising abatement strategies are also highlighted, along with potential solutions and the way forward in tackling these deficiencies. Such a comprehensive analysis is necessary to set realistic emission targets and to ensure the effectiveness of proposed emission abatement strategies in the management of manure.

\section{Methodology}

A meta-analytical approach was used to determine emission reductions for the different manure abatement options. The section below describes the methodology used to define the system boundaries, selection of data sources, and estimation of emission reductions.

\section{Manure Management Chain and Emission Abatement Options}

Livestock production and management is a source of emissions. In this paper, we focus on those activities that are related to manure management, as these processes are strongly related. The manure management chain consists of various stages, from animal feeding to the application of manure to soils. Animal feeding is included, since it alters manure characteristics and subsequently affects emissions through the entire manure management chain. Each stage is associated with emissions of the relevant gases $\left(\mathrm{CH}_{4}, \mathrm{~N}_{2} \mathrm{O}\right.$, or $\left.\mathrm{NH}_{3}\right)$ in varying amounts and rates. However, in each stage, emissions can be influenced by management practices (e.g., frequent removal of manure, covering manure, etc.) or by technological intervention (e.g., low protein animal diets, manure acidification, installation of scrubbers, etc.). Here, we employed a literature review to identify prominent abatement options associated with different manure management stages. The manure management chain, along with the abatement options considered, is illustrated in Fig. 1. In our selection of abatement options, we took advantage of the United Nations Economic Commission for Europe's (UNECE) recommendations (Bittman et al., 2014) and the recent literature (Del Prado et al., 2013; Montes et al., 2013; Oenema et al., 2014), which allowed us to arrive at a set of consistent abatement options. Manure-related emissions include emission fluxes from urine and feces excreted in animal housing, during storage and further treatment, and after application to agricultural soils. Direct $\mathrm{CH}_{4}$ emissions from animals, specifically "enteric fermentation," are not included in the current analysis, as these would not entail manure management. Also, since the focus of this study pertains to housed animals, emissions from grazing were excluded. Furthermore, we take advantage of the clear separation between liquid and solid manure systems. This paper covers the interrelations of the liquid manure systems for the animal types (pigs and cattle) that contribute to a majority of manure emissions, but the analysis did not distinguish between them. Limiting the scope to only liquid manure management rules out abatement strategies such as slurry separation, as this would entail managing emissions from the solid part of the separated slurry in downstream stages during storage and application of solid manure. Although this is sufficient for the objectives of this study, a comprehensive analysis inclusive of all abatement options for both solid and liquid manure with a greater detail of separation on the basis of animal type is important to fully understand the potential of emission abatement options for manure management.

\section{Selection of Data Sources}

Emission reduction potentials for the identified abatement options were estimated using effective observations from published literature according to the methods described in recent studies that focus on emission abatement in manure management systems (Hou et al., 2015, 2017; Wang et al., 2017). The selection criteria were as follows: (i) the animal category was either cattle or pigs; (ii) the study was subject to at least one of the eight chosen abatement options; (iii) the study measured and reported either $\mathrm{NH}_{3}$ and/or GHG emissions for at least one of the manure management stages of housing, treatment, storage, or application; (iv) the study included data on reference treatments and base emissions; and (v) the article was peer reviewed and available in English. This resulted in a selection of 89 peer-reviewed papers and reports measuring $\mathrm{NH}_{3}$ and/or GHG emissions from on-farm and experimental farm settings. This corresponded to 465 individual observations, which were used in the analysis. The reference systems, abatement options, 


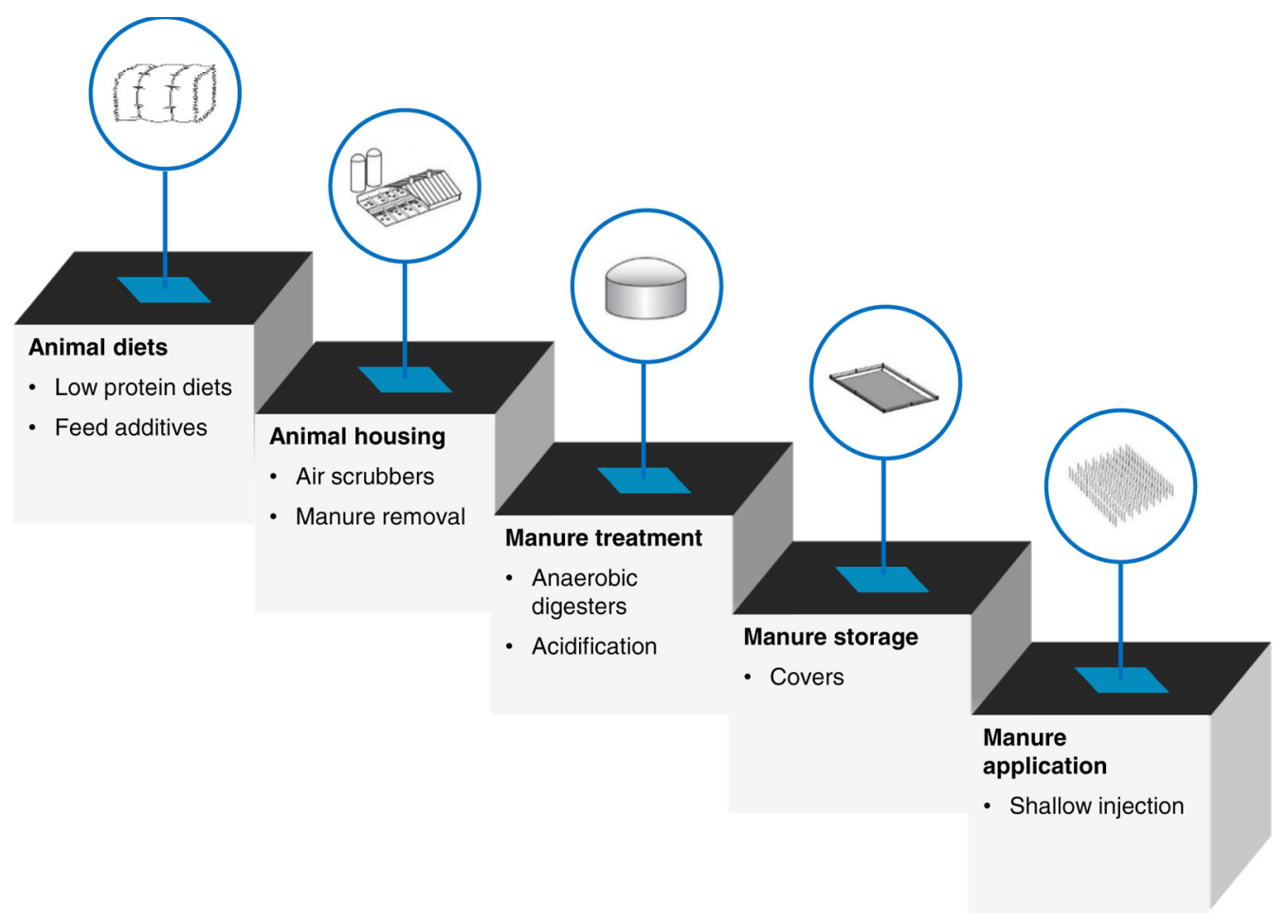

Fig. 1. Stages in the manure management chain and associated abatement options considered in the meta-analytical approach.

and number of emission observations are reported in Table 1 . A full list of studies separated by manure management stage and animal type for all abatement options, along with the emission reductions and references, is provided in the supplemental information (Supplemental Tables S1 to S5).

\section{Estimation of Emission Reduction Potentials and Interactions}

Emission reductions for abatement options were calculated relative to a reference system. The emission reductions were derived according to Eq. [1]:

$\mathrm{AE}=\left(E_{\mathrm{abt}} / E_{\mathrm{ref}}-1\right) 100$

where $\mathrm{AE}$ is the emission abatement efficiency (\%), $E_{\text {abr }}$ refers to emissions with abatement measures, and $E_{\text {ref }}$ is the emissions under the reference scenario. The units for the emissions corresponding to the reference scenario and with abatement measures vary depending on the measurement methods and units used in individual studies. This allowed for a normalization of emission reductions in percentage terms to arrive at relative changes caused by an abatement option to the different gases, even if only few studies considered the effect of an abatement option on all three of them $\left(\mathrm{CH}_{4}, \mathrm{~N}_{2} \mathrm{O}\right.$ and $\left.\mathrm{NH}_{3}\right)$. A negative value of the emission abatement efficiency indicates a decrease in emissions due to the abatement option used. It is worth mentioning that even though this study aims to quantify the emission reductions over the whole manure management chain, the overall emission reductions calculated for a particular abatement option is an average of a multitude of emission reduction estimates typically measured at a single manure management stage or occasionally covering multiple stages. For example, in the case of feeding, the overall emission reduction is an average of measurements reported at housing, storage, and application stages. Since variability in emission trends could arise between stages, the emission reductions from individual stages from which the overall emission reductions are calculated while using a particular abatement option has been explicitly mentioned in the text.

\section{Statistical Analyses}

Descriptive statistics were used to quantify and describe the emission reductions. Means and SDs were calculated and reported for all existing datasets. High variability occurred in several instances, with SDs exceeding the mean value such that

Table 1. Number of emission observations, reference system, and list of abatement options included in the meta-analytical approach

\begin{tabular}{|c|c|c|c|c|c|}
\hline \multirow{2}{*}{ Abatement stage } & \multirow{2}{*}{ Reference system } & \multirow{2}{*}{ Abatement options } & \multicolumn{3}{|c|}{ Sample size (observations) } \\
\hline & & & $\mathrm{N}_{2} \mathrm{O}$ & $\mathrm{CH}_{4}$ & $\mathrm{NH}_{3}$ \\
\hline \multirow[t]{2}{*}{ Feeding } & High protein feeds & Reduced crude protein & 11 & 10 & 72 \\
\hline & & Additives & 3 & 6 & 19 \\
\hline \multirow[t]{2}{*}{ Housing } & Liquid manure housing systems & Air scrubbers & 5 & 5 & 23 \\
\hline & & Frequent removal & 4 & 4 & 5 \\
\hline \multirow[t]{2}{*}{ Treatment } & No treatment & Anaerobic digesters & 26 & 7 & 17 \\
\hline & & Acidification & 6 & 18 & 33 \\
\hline Storage & No cover & Covers & 18 & 27 & 50 \\
\hline Application technique & Surface spreading & Shallow injection & 22 & - & 77 \\
\hline
\end{tabular}


reported trends may be merely indicative. The use of complex statistical models was not possible due to a small sample size. This is in line with the primary focus of the study to compile descriptive arguments for observed trends and interactions between various abatement options on GHGs and $\mathrm{NH}_{3}$, rather than estimate emission reductions on an absolute scale.

\section{Results}

The section below quantifies the emissions reductions from various abatement options for the manure management chain. The abatement options and emission reductions are categorized according to various stages involved in manure management, as illustrated in Fig. 1. As outlined above, emission reductions were estimated using either single-stage or multistage measurements corresponding to the functioning of the abatement option and included the analysis of all three gases $\left(\mathrm{CH}_{4}, \mathrm{~N}_{2} \mathrm{O}\right.$, and $\left.\mathrm{NH}_{3}\right)$ collectively. Table 2 reports the average emission reductions, along with the SDs, for the selected abatement options. The emission reduction estimates indicate variability, which in some cases can be attributed to specific reasons and should not be taken as blanket uncertainty. Variations exist, as measurements have been made at different stages of the manure management chain, using different methods, and as the reduction estimates are derived from various scales ranging from laboratory to field. Other influencing factors related to specific abatement options that affect emission reductions and induce variability will be discussed in the sections below.

\section{Feeding Strategies}

Manipulating animal diets has implications on emissions from livestock manure (Oenema et al., 2014). Reducing the dietary crude protein (CP) content of animal diets and the inclusion of feed additives such as fiber, enzymes, and acids are some of the abatement options reported to lower gaseous emissions from the manure management chain.

\section{Reduced Crude Protein}

Ammonia emissions decrease with a reduction in dietary CP levels. (Oenema et al., 2014). Reduced CP in animal diets decreases the amount of $\mathrm{N}$ in manure (Agle et al., 2010), along with lowering the manure $\mathrm{pH}$. This leads to higher incorporation of $\mathrm{N}$ into a stable state as microbial protein (i.e., organic $\mathrm{N}$ ), thereby decreasing the ratio of ammonium $\left(\mathrm{NH}_{4}^{+}\right)$to total $\mathrm{N}$ in manure, and consequently $\mathrm{NH}_{3}$ emissions (Le et al., 2009).
Some studies used external amino acid supplementation along with reduced $\mathrm{CP}$ to balance the feed $\mathrm{N}$ intake. This exogenous supplementation improves $\mathrm{N}$ utilization and reduces $\mathrm{N}$ excretion (Panetta et al., 2006; Madrid et al., 2013; Montalvo et al., 2013). It also leads to a decrease in $\mathrm{NH}_{3}$ emissions, but the implications of amino acid supplementation are beyond the scope of this work. In the present study, the CP levels for reference diets before a reduction in $\mathrm{CP}$ were averaged at $17.2 \pm 2 \%$ (maximum $=22 \%$, minimum $=11 \%$ ) for both pigs and cattle. The results from the analysis indicate a reduction in $\mathrm{NH}_{3}$ emissions by 42 $\pm 21 \%$ (Table 2) relative to conventional diets with higher CP. This corresponds to a $13 \pm 7 \%$ reduction in $\mathrm{NH}_{3}$ emissions per \%-point decrease in CP, where \%-point is the difference between two CP levels (e.g., a change in CP level from 16 to $14 \%$ is expressed as a reduction of two \%-points). The emission reductions were consistent irrespective of the specific manure management stage. Ammonia emissions decreased by $41 \pm 22,41 \pm 19$, and $47 \pm 24 \%$ with reduced CP when measured at the housing, storage, and application stages, respectively.

In contrast with $\mathrm{NH}_{3}, \mathrm{CH}_{4}$ emissions increased with a reduction in dietary CP. At lower CP levels, the digestibility of fiber is lower, and when this undigested fiber is excreted with manure, it provides additional carbon for methanogenesis, generating $\mathrm{CH}_{4}$ during manure storage (Külling et al., 2001). The estimates from the data collected indicate an overall increase in $\mathrm{CH}_{4}$ emissions by $71 \pm 131 \%$ (Table 2), mainly from manure storage. In terms of a unit reduction in \%-point $\mathrm{CP}$, this equates to an increase in $\mathrm{CH}_{4}$ emissions of $20 \pm 30 \%$. Nitrous oxide emissions tend to decrease with reduced CP in animal diets (Külling et al., 2001; Lee et al., 2012). Nitrous oxide emissions were negligible at the housing stage, but emissions were reduced by $52 \pm 39$ and $17 \%$ (only one observation) at the storage and application stages, respectively. Averaged over all manure management stages, lowering dietary $\mathrm{CP}$ reduced $\mathrm{N}_{2} \mathrm{O}$ emissions by $30 \pm 38 \%$ (Table 2), which is a decrease in $\mathrm{N}_{2} \mathrm{O}$ emissions by $9 \pm 12 \%$ per \%-point reduction in $\mathrm{CP}$. This is primarily due to the lower $\mathrm{N}$ content in the manure. The variability in emission reductions is due to certain factors associated with reduced $\mathrm{CP}$ that could contribute to an increase in $\mathrm{N}_{2} \mathrm{O}$ emissions during manure storage. As described above for $\mathrm{CH}_{4}$, the digestibility of fiber in the digestive tract of animals decreases with a reduction in CP. At the manure storage stage, this enhances crust formation, which may lead to higher $\mathrm{N}_{2} \mathrm{O}$ emissions due to the creation of aerobic and anaerobic zones, leading to nitrification and denitrification (Külling et al., 2003).

Table 2. Emission changes (relative to reference). Compilation from a literature survey comprising peer reviewed studies (see explanation and text in the following sections).

\begin{tabular}{|c|c|c|c|c|c|}
\hline \multirow{2}{*}{ Abatement stage } & \multirow{2}{*}{ Reference scenario } & \multirow{2}{*}{ Abatement options } & \multicolumn{3}{|c|}{ Emission changest } \\
\hline & & & $\mathrm{N}_{2} \mathrm{O}$ & $\mathrm{CH}_{4}$ & $\mathrm{NH}_{3}$ \\
\hline & & & & $\%$ & \\
\hline \multirow[t]{2}{*}{ Feeding } & High protein feeds & Reduced crude protein & $-30(38)$ & $+71(131)$ & $-42(21)$ \\
\hline & & Additives & $+9(9)$ & $+20(33)$ & $-9(34)$ \\
\hline \multirow[t]{2}{*}{ Housing } & Liquid manure housing systems & Air scrubbers & $+164(270)$ & $-6(21)$ & $-59(39)$ \\
\hline & & Frequent removal & $-41(17)$ & $-55(5)$ & $-22(29)$ \\
\hline \multirow[t]{2}{*}{ Treatment } & No treatment & Anaerobic digesters & $-23(44)$ & $-29(116)$ & $-3(45)$ \\
\hline & & Acidification & $-55(45)$ & $-74(22)$ & $-60(28)$ \\
\hline Storage & No cover & Covers & $>+500$ & $-11(34)$ & $-65(29)$ \\
\hline Application technique & Surface spreading & Injection & $+259(416)$ & - & $-71(25)$ \\
\hline
\end{tabular}

† Numbers marked in bold with a "+" sign indicates an increase in emissions relative to the reference. 


\section{Feed Additives}

Supplementing animal diets with feed additives such as fiber, acids, and enzymes generally led to a decrease in $\mathrm{NH}_{3}$ emissions. In the case of additives, the reference CP levels were 17.6 $\pm 2.2 \%$ (maximum $=22 \%$, minimum $=12 \%)$ on average for both animal types. Analysis of emission reduction estimates indicates a reduction of $27 \pm 20 \%$ at the housing level and an increase of $5 \pm 37 \%$ during storage. Combined estimates for all feed additives aggregated over housing and storage show a $\mathrm{NH}_{3}$ reduction of $9 \pm 34 \%$ (Table 2). Although there is a difference in emission trends between housing and storage stages, the variability in emission reductions mainly stems from the effect of different feed additives on $\mathrm{NH}_{3}$ emissions. Enzyme addition to boost nutrient digestibility in pig diets may lead to higher $\mathrm{NH}_{3}$ emissions. Addition of enzymes leads to the degradation of $\beta$-glucan in barley (Hordeum vulgare L.)-based diets, leading to more urinary $\mathrm{N}$. Furthermore, enzyme addition reduces microbial fermentation and increases the slurry $\mathrm{pH}$ (O'Connell et al., 2006). Both these factors enhance $\mathrm{NH}_{3}$ generation. On the other hand, inclusion of acids and fiber as feed additives leads to a reduction in $\mathrm{NH}_{3}$ emissions (Hansen et al., 2007; Galassi et al., 2010; Montalvo et al., 2013). Acids reduce urinary pH, which leads to decreased $\mathrm{NH}_{3}$ emissions, and fibers affect the manure composition by shifting the $\mathrm{N}$ from urine to feces, which is less susceptible to $\mathrm{NH}_{3}$ volatilization (Hansen et al., 2007; Lynch et al., 2007, 2008; Montalvo et al., 2013). Moreover, addition of certain fibers such as inulin leads to a lower manure $\mathrm{pH}$, resulting in a subsequent decrease in $\mathrm{NH}_{3}$ emissions (Hansen et al., 2007; Lynch et al., 2007). However, addition of some fibers such as wheat (Triticum aestivum L.) bran was not as effective as other fibers (inulin and sugar beet [Beta vulgaris L. ssp. vulgaris] pulp) (Galassi et al., 2010). This is because wheat bran contains low levels of soluble nonstarch polysaccharides, which lead to a smaller shift of $\mathrm{N}$ from urine to feces. In addition, wheat bran is somewhat resistant to microbial fermentation; thus, the $\mathrm{pH}$ values of slurries were not reduced (Galassi et al., 2010).

Feed additives led to slight increases in overall $\mathrm{CH}_{4}$ emissions by $20 \pm 33 \%$ (Table 2). Estimates show an increase in $\mathrm{CH}_{4}$ emissions of $17 \pm 33 \%$ from housing and $21 \pm 42 \%$ during storage. Addition of fiber led to higher $\mathrm{CH}_{4}$ emissions, which could be due to an increase in degradable fiber in manure (Montalvo et al., 2013). Although lower $\mathrm{pH}$ generally leads to decreased $\mathrm{CH}_{4}$ emissions, the addition of benzoic acid did not have a significant impact on $\mathrm{CH}_{4}$ emissions (Montalvo et al., 2013). The effect of feed additives (both acids and fiber) on $\mathrm{N}_{2} \mathrm{O}$ emissions during the housing stage indicated an increase in emissions by $9 \pm 9 \%$ (Table 2 ).

\section{Animal Housing}

Cattle and pig housing also contribute to manure emissions. Better management of manure and installation of appropriate abatement technology could help abate these emissions. In this section, the abatement potential of air scrubbers and the frequent removal of manure are discussed in terms of $\mathrm{NH}_{3}$ and $\mathrm{GHG}$ emissions. It is important to note that air scrubbing systems are mainly applicable to pig and poultry housing, which usually use forced ventilation (required for scrubber techniques), in contrast with naturally ventilated cattle housing systems.

\section{Air Scrubbers}

Chemical and biological scrubbers have been used to reduce $\mathrm{NH}_{3}$ and odor emissions from pig and poultry housing facilities (Feilberg and Sommer, 2013). Both chemical and biological scrubbers have the potential to reduce $\mathrm{NH}_{3}$ emissions. Overall estimates indicate reduction in emissions from housing by $59 \pm 39 \%$ (Table 2 ) with the use of air scrubbers. However, chemical scrubbers are more effective in reducing $\mathrm{NH}_{3}$ emissions than biological scrubbers. In the case of chemical scrubbers, the addition of acid (usually sulfuric acid) reduces the $\mathrm{pH}$ of washing water, which absorbs the dissolved $\mathrm{NH}_{3}$, forming an ammonium salt solution (Van der Heyden et al., 2015). Reduction estimates show that chemical scrubbers can reduce $\mathrm{NH}_{3}$ emissions by $90 \pm 8 \%$. On the contrary, biological scrubbers have lower $\mathrm{NH}_{3}$ reductions of $46 \pm 40 \%$. In biological scrubbers, the washing liquid captures $\mathrm{NH}_{4}^{+}$and converts it into nitrate $\left(\mathrm{NO}_{3}^{-}\right)$with the help of ammonia-oxidizing bacteria. The low $\mathrm{NH}_{3}$ removal efficiencies in biological scrubbers, as compared with chemical scrubbers, is caused by the release of untreated air into the environment from operational inadequacies and inhibition of biological material from accumulation of $\mathrm{NH}_{4}^{+}$and $\mathrm{NO}_{3}^{-}$(Martens et al., 2001).

Greenhouse gases cannot be removed using chemical scrubbers, as these gases have lower water solubility than $\mathrm{NH}_{3}$. In biological scrubbers, $\mathrm{CH}_{4}$ emission reductions were negligible, with reductions of $6 \pm 21 \%$ (Table 2). However, the use of biological scrubbers might lead to an increase in $\mathrm{N}_{2} \mathrm{O}$ emissions. The longer bed residence time, along with the nitrification and denitrification processes in the presence of nitrifying bacteria, may lead to a conversion of $\mathrm{NH}_{3}-\mathrm{N}$ to $\mathrm{NO}_{3}{ }^{-}$and then $\mathrm{N}_{2} \mathrm{O}$ (Melse and Mosquera, 2014; Van der Heyden et al., 2015). All the observations analyzed in this study pertaining to biological scrubbers revealed an increase in $\mathrm{N}_{2} \mathrm{O}$ emissions of $164 \pm 270 \%$ (Table 2).

\section{Frequent Removal of Manure}

Ammonia emissions from animal housing are dependent on the surface area of manure in contact with air. A major share of the $\mathrm{NH}_{3}$ emissions is generated from fresh manure, especially urine. Hence, regular removal of fresh manure can reduce $\mathrm{NH}_{3}$ emissions (Amon et al., 2007; Ivanova-Peneva et al., 2008). Results from the analysis show a reduction in $\mathrm{NH}_{3}$ emissions of $22 \pm 29 \%$ (Table 2) from animal housing facilities with daily or weekly removal of manure. Methane and $\mathrm{N}_{2} \mathrm{O}$ emissions from animal housing systems are also dependent on the total amount of manure (Amon et al., 2007). Frequently removing manure from animal houses reduces the accumulation of manure and decreases $\mathrm{CH}_{4}$ and $\mathrm{N}_{2} \mathrm{O}$ emissions by $55 \pm 5$ and $41 \pm 17 \%$ (Table 2), respectively. Lower temperatures during outside storage of the removed manure are likely to reduce $\mathrm{CH}_{4}$ emissions, compared with manure stored indoors (Amon et al., 2007). Hence, the overall emission balance may be improved with frequent manure removal to outside storage

\section{Manure Treatment}

Manure treatment refers to techniques by which manure can be handled to ensure lower emissions and, in some cases, generate energy. Among the different manure treatment options available, anaerobic digestion and acidification of manure are discussed here. 


\section{Anaerobic Digestion}

Anaerobic digestion involves the degradation of organic matter to generate $\mathrm{CH}_{4}, \mathrm{CO}_{2}$, and other gaseous byproducts. The generated gases, particularly $\mathrm{CH}_{4}$, can act as an additional renewable energy source when captured. Hence, anaerobic digestion is not only a direct emission abatement technique but can also produce cogeneration credits by substituting conventional energy sources (Roos et al., 2004).

Literature on the effects of anaerobic digestion on $\mathrm{NH}_{3}$ emissions reveals mixed results (Chantigny et al., 2007) with considerable variability. Estimates here showed an increase in $\mathrm{NH}_{3}$ emissions by $13 \pm 76 \%$ during the storage of digestate and a decrease of $8 \pm 34 \%$ when applied to the soils. Overall estimates averaged over the storage and application stages indicate a tendency for a small decrease in $\mathrm{NH}_{3}$ emissions by $3 \pm 45 \%$ (Table 2) for digestates relative to raw slurry. Some studies claim that anaerobic digestion decreases the dry matter content of manure, allowing for greater infiltration of digestate when applied to the soils, which could reduce $\mathrm{NH}_{3}$ emissions from the soil surface (Chantigny et al., 2009). Other studies suggest that the process of anaerobic digestion increases total ammoniacal nitrogen concentration and the $\mathrm{pH}$ of digested manure, which might lead to an increase in $\mathrm{NH}_{3}$ emissions during storage and application of digestate (Petersen and Sommer, 2011). Ammonia emissions are also dependent on site-specific factors and management practices during the storage and application of digested manure. For example, an increase in $\mathrm{NH}_{3}$ emissions was observed when digestate was stored without a cover (Amon et al., 2006). Injection of digested slurry during field application can also reduce $\mathrm{NH}_{3}$ emissions, relative to surface spreading (Nyord et al., 2012). This highlights the importance of properly handling anaerobic digestates during storage and field application to optimize the $\mathrm{NH}_{3}$ emission reduction potential.

In the case of $\mathrm{CH}_{4}$ emissions, estimates from the present study show a reduction in emissions by $29 \pm 116 \%$ (Table 2), primarily during the storage of digestate. Variability in emissions exists due to varying $\mathrm{CH}_{4}$ recovery rates from manure of different animal types and the influence of external factors such as storage temperature, duration, and structure of manure storage systems (Massé et al., 2011). Care should also be taken to prevent $\mathrm{CH}_{4}$ losses from improper operation, uncontrolled losses, and leaks from anaerobic digestion systems, which could make the system ineffective in reducing $\mathrm{CH}_{4}$ and other GHGs (Montes et al., 2013).

Nitrous oxide emissions increased by $20 \pm 41 \%$ during digestate storage and decreased by $29 \pm 43 \%$ during the application of digestate. Averaging the $\mathrm{N}_{2} \mathrm{O}$ emission reductions from treatment, storage, and application of digestate indicates reductions of $23 \pm 44 \%$ (Table 2). Clemens et al. (2006) reported higher $\mathrm{N}_{2} \mathrm{O}$ emissions from digested slurry relative to untreated slurry during summer storage. They associated the increase in $\mathrm{N}_{2} \mathrm{O}$ emissions to the differences in $\mathrm{NH}_{4}-\mathrm{N}$ content, which could influence nitrification and denitrification processes. Another study (Wang et al., 2014b) also revealed elevated emissions of $\mathrm{N}_{2} \mathrm{O}$ during the storage of digestate. The authors attributed the increase in emissions to the high ventilation rate, high storage temperature, and low depth of manure storage. During manure application, the decomposition of organic matter after anaerobic digestion has a twofold effect on reducing $\mathrm{N}_{2} \mathrm{O}$ emissions. First, it makes a higher share of $\mathrm{N}$ directly available to plants due to the mineralization of organic $\mathrm{N}$ to ammonium (Walsh et al., 2012), and second, it limits the activity of $\mathrm{N}_{2} \mathrm{O}$-forming microorganisms dependent on fresh organic matter for their energy supply (Montes et al., 2013). However, Thomsen et al. (2010) suggested that factors such as manure composition and external conditions, such as water-filled pore space and the balance between oxygen supply and demand, could lead to increases in $\mathrm{N}_{2} \mathrm{O}$ emissions when digestate was applied to soils relative to untreated slurry.

\section{Acidification of Manure}

Acidification refers to the addition of acids to manure. Acids can be introduced into the manure management chain right from the feeding stage, as discussed above. Here, we only investigate the effect of acids during housing and storage, and also further downstream during the application of manure to soils.

Acidification has not been widely adopted in the United States and some European countries due to acid hazard, foam formation, and costs that were attributed to this technology until recently (Fangueiro et al., 2015). However, considerable progress has been made in manure acidification, and it is recognized as one of the best available technologies to reduce $\mathrm{NH}_{3}$ emissions in Denmark (Kai et al., 2008). Moreover, it has recently been assigned as a category-one abatement strategy in the UNECE guidance document to reduce $\mathrm{NH}_{3}$ emissions from manure (Bittman et al., 2014). Addition of acids reduces the $\mathrm{pH}$ level of manure, thereby inhibiting the activity of urease-producing bacteria, shifting the equilibrium from $\mathrm{NH}_{3}-\mathrm{N}$ to favor $\mathrm{NH}_{4}^{+}$and consequently lowering $\mathrm{NH}_{3}$ emissions (Jensen, 2002). Additionally, as a result of retaining $\mathrm{N}$ in the manure, manure acidification is valuable during land application since the acidified manure has more plant available N (Montes et al., 2013). Ammonia emissions decreased by $77 \pm 11 \%$ for housing, $63 \pm 30 \%$ during storage, and 43 $\pm 18 \%$ after the application of acidified slurry. Averaged over all manure management stages, $\mathrm{NH}_{3}$ emissions were reduced by $60 \pm 28 \%$ (Table 2). All the studies used here pertaining to manure acidification revealed consistent reductions in $\mathrm{NH}_{3}$, highlighting the potential of acidification as a promising $\mathrm{NH}_{3}$ abatement technique. However, the results were sensitive to the final $\mathrm{pH}$ level achieved with the addition of acids. Former assessments indicate that $\mathrm{pH}$ levels lower than six were effective in reducing $\mathrm{NH}_{3}$ emissions (Wang et al., 2014a).

Although acidification shows promise as a $\mathrm{NH}_{3}$ abatement option, its implication on GHGs is not well documented. Our evaluation indicates that acidification of manure can reduce $\mathrm{CH}_{4}$ emissions by $74 \pm 22 \%$ (Table 2) during the storage of manure. Studies have reported that methanogenesis is limited by addition of acids, particularly sulfates (Petersen et al., 2012, 2014). Methanogenic activity leading to $\mathrm{CH}_{4}$ emissions is prevalent between $\mathrm{pH}$ levels of 6.5 and 8.5. Acidification of manure generally reduces the $\mathrm{pH}$ to lower levels (below six), inhibiting methanogenesis and subsequently reducing $\mathrm{CH}_{4}$ emissions (Wang et al., 2014a). Effects of acidification on $\mathrm{N}_{2} \mathrm{O}$ emissions were mixed. Addition of sulfuric acid led to overall reductions in $\mathrm{N}_{2} \mathrm{O}$ emissions by $17 \pm 30 \%$ (Table 2) during the storage and application of acidified slurry. The reduction in $\mathrm{N}_{2} \mathrm{O}$ emissions was due to the decreased activity of bacterial nitrifiers with the lowering of slurry pH (Owusu-Twum et al., 2017). One of the studies, 
however, reported no change in $\mathrm{N}_{2} \mathrm{O}$ emissions during storage of acidified slurry (Petersen et al., 2014). The authors suggested that they may have disturbed surface crust formation, a prime source of $\mathrm{N}_{2} \mathrm{O}$ emissions, during acid mixing in the experiment, leading to no change in emissions. Lactic acid reduced $\mathrm{N}_{2} \mathrm{O}$ emissions by $90 \%$ or more due to the lowering of slurry $\mathrm{pH}$ (Berg et al., 2006b). The use of nitric acid, on the other hand, adds $\mathrm{N}$ to the system and also stimulates denitrification, leading to large increases in $\mathrm{N}_{2} \mathrm{O}$ emissions (Berg et al., 2006b). As nitric acid is not currently considered a practical acidification technique, it was omitted from our analysis. Overall estimates indicate $\mathrm{N}_{2} \mathrm{O}$ reduction of $55 \pm 45 \%$ (Table 2), comprising $\mathrm{N}_{2} \mathrm{O}$ reductions of $56 \pm 51 \%$ during storage of acidified manure and $52 \%$ when applied to the soils. The variations in emission reduction stem from the selection of appropriate acid and application rates, which are acknowledged in the published literature (Petersen and Sommer, 2011).

\section{Manure Storage}

Manure is typically stored after removal from animal houses or after manure treatment for various reasons (e.g., appropriate timing of soil application, limited land near the livestock operation for application, time restraints of work staff, etc.). Improper storage of manure leads to physical and chemical degradation. A result of this degradation is emissions, odors, loss of fertilizer value, and also high hauling cost when exposed to rain. A feasible emission abatement option during manure storage is the use of covers. Covers include the use of chopped straw, wooden lids, granules, floating films, plastic covers, roofs, and also the use of other materials like oil, peat, etc. (Amon et al., 2014).

Similar to animal housing, the extent of $\mathrm{NH}_{3}$ emissions depend on the surface area of exposed manure. Since covers form a barrier and can retain the $\mathrm{N}$ without exposing it to air, they can reduce emissions of $\mathrm{NH}_{3}$. Straw covers, granules, wooden lids, plastic sheets, natural crust, and peat can reduce $\mathrm{NH}_{3}$ emissions when used as covers (Amon et al., 2014). Overall reductions in $\mathrm{NH}_{3}$ from using covers were $65 \pm 29 \%$ (Table 2). Among the different covering materials analyzed, the use of plastic films, granules, and peat were more effective in reducing $\mathrm{NH}_{3}$ emissions than other covering materials like straw, wooden lids, and the natural formation of surface crusts. Some studies also used covers in conjunction with acids (lactic acid), which also yielded favorable reductions in $\mathrm{NH}_{3}$ emissions (Berg et al., 2006a).

Results from the analysis indicate a reduction in $\mathrm{CH}_{4}$ emissions by $12 \pm 33 \%$ (Table 2) with the use of covers. Oxidation of $\mathrm{CH}_{4}$, limiting variations in moisture content, maintaining a stable $\mathrm{CH}_{4}$ concentration above the stored manure, and avoiding $\mathrm{CH}_{4}$ losses from ebullition (i.e., bubbling or foaming) could reduce $\mathrm{CH}_{4}$ emissions from stored manure (Rodhe et al., 2012). Although the use of covers generally favors mechanisms that reduce $\mathrm{CH}_{4}$ emissions (Amon et al., 2007; Rodhe et al., 2012), the emission patterns vary among individual studies. These studies argue that the microbial processes governing $\mathrm{CH}_{4}$ production with certain covering materials (straw, formation of surface crusts) and the influence of manure storage conditions (time, weather, etc.) affect $\mathrm{CH}_{4}$ emissions (Hansen et al., 2009; Petersen et al., 2013).
The use of covers led to large increases in $\mathrm{N}_{2} \mathrm{O}$ emissions $(>500 \%$, Table 2$)$. This estimate was accompanied by high variability, due to contrasting emission trends among all the covering materials analyzed. Certain covering materials such as formation of surface crust, addition of straw, and the use of granules tended to increase emissions of $\mathrm{N}_{2} \mathrm{O}$ (Berg et al., 2006a; Hansen et al., 2009; VanderZaag et al., 2009; Petersen et al., 2013). These types of covering materials create both aerobic and anaerobic zones, providing suitable conditions for the nitrification and denitrification processes responsible for $\mathrm{N}_{2} \mathrm{O}$ emissions (Clemens et al., 2006). Some studies argue that the use of impermeable covers like wooden lids or plastic films could reduce $\mathrm{N}_{2} \mathrm{O}$ emissions through the elimination of oxygen in the headspace (Clemens et al., 2006). External factors such as moisture content of the crust, manure storage time, and weather conditions during storage may also influence the emission patterns of $\mathrm{N}_{2} \mathrm{O}$ (Rodhe et al., 2012; Petersen et al., 2013). The combined use of covering materials or covers with manure acidification also produced contradictory results in terms of $\mathrm{N}_{2} \mathrm{O}$ emissions (Berg et al., 2006a; Clemens et al., 2006). Further research is needed to understand the mechanism of $\mathrm{N}_{2} \mathrm{O}$ emissions with the use of covers and possible interactions with other emission abatement options.

\section{Manure Application}

Animal manure is rich in micro- and macronutrients essential for plant growth. Addition of manure to soils increases the organic matter, along with enhancing numerous other soil properties (Hristov et al., 2013). However, the application of manure is associated with $\mathrm{NH}_{3}$ and $\mathrm{N}_{2} \mathrm{O}$ emissions. Methane emissions from manure application are generally low due to carbon uptake by the soils and the existence of an aerobic environment in most cropping systems (Goulding et al., 1996). A study by Sherlock et al. (2002) estimated $\mathrm{CH}_{4}$ losses to be $0.08 \%$ of the carbon applied, as compared with 22.5 and $2.1 \%$ of the nitrogen applied lost as $\mathrm{NH}_{3}$ and $\mathrm{N}_{2} \mathrm{O}$ after manure application. In terms of warming potentials, this translated to $3700 \mathrm{~kg} \mathrm{CO}_{2} \mathrm{e}$ for $\mathrm{N}_{2} \mathrm{O}$ compared with $29 \mathrm{~kg} \mathrm{CO}_{2} \mathrm{e}$ for $\mathrm{CH}_{4}$. Hence, $\mathrm{CH}_{4}$ emissions from manure application can be considered negligible for the purposes of this study (Montes et al., 2013). Although many modes of manure application are available, this study analyzed only shallow injection relative to surface spreading as the reference.

On average, shallow injection reduced $\mathrm{NH}_{3}$ emissions by 71 $\pm 25 \%$ (Table 2) as compared with surface spreading of manure. These high reductions in $\mathrm{NH}_{3}$ emissions were due to the reduced contact of manure with the atmosphere (Huijsmans et al., 2003). Manure injection led to major increases in $\mathrm{N}_{2} \mathrm{O}$ emissions by 259 $\pm 416 \%$ (Table 2). This could be due to creation of high moisture anaerobic zones that promote denitrification (Vallejo et al., 2005; Dell et al., 2011; Duncan et al., 2017). However, there was high variability in estimates of increased $\mathrm{N}_{2} \mathrm{O}$ emissions from shallow injection. A review study by Webb et al. (2010) underlines some of the reasons for this variability. Oxygen availability, preexisting $\mathrm{N}$ concentrations in the soil, soil moisture content, and the length of the diffusion path to the soil surface could influence the impact of shallow injection on the amount of $\mathrm{N}_{2} \mathrm{O}$ emissions. In some cases, this could even reduce or nullify the impact of shallow injection on $\mathrm{N}_{2} \mathrm{O}$ emissions. 


\section{Implication on Emission Abatement Strategies}

The results discussed in this study may play an important role in developing consistent procedures in the design of emission abatement strategies. Some of the key elements that could aid in selection and implementation of abatement options, along with prospects to further improve effectiveness of emission abatement strategies, are described below.

\section{Importance of Proper Clustering and Classification}

The estimated emission reductions for the different abatement strategies are characterized by variability. Although inherent uncertainty due to experimental design, measurement technologies, and site-specific factors contributes to this variability, in some cases, this variability can be explained and disentangled. For example, in the case of dietary manipulation, lowering $\mathrm{CP}$ in animal diets reduced overall $\mathrm{NH}_{3}$ emissions by $42 \pm 21 \%$. However, a closer analysis indicates an influence of the level of CP reductions on $\mathrm{NH}_{3}$ emissions. Reducing CP levels by less than two \%-points decreases $\mathrm{NH}_{3}$ emissions by $26 \pm 21 \%$, whereas a reduction in CP levels greater than five \%-points reduces $\mathrm{NH}_{3}$ emissions by $51 \pm 21 \%$. Feed composition could also affect $\mathrm{NH}_{3}$ emissions from reduced $\mathrm{CP}$ in animal diets. For example, a CP reduction from 22 to $16 \%$ for barley-based diets in pigs showed a more pronounced effect on lowering $\mathrm{NH}_{3}$ emissions, rather than for wheat. This is because the relatively lower $\beta$-glucan content in wheat led to more $\mathrm{N}$ in urine than barley, generating higher $\mathrm{NH}_{3}$ emissions (O'Connell et al., 2006). As far as the difference between cattle and pigs is concerned, estimates indicate a greater reduction in $\mathrm{NH}_{3}$ by 16 $\pm 6 \%$ per unit percentage decrease in CP for cattle, compared with $11 \pm 6 \%$ for pigs. A similar comparison distinguishing between animal types for reduced dietary CP and feed additive supplementation on $\mathrm{GHG}$ and $\mathrm{NH}_{3}$ emissions could not be conducted due to limited data availability. An assessment of the results also highlights the importance of accounting for the differences in biological and physical aspects of animals when quantifying emission reductions from lowering $\mathrm{CP}$ in animal diets. For example, the effect of reduced CP on $\mathrm{NH}_{3}$ emissions was magnified in growing pigs as compared with pigs in the finishing stage, highlighting the influence of growth stage on $\mathrm{NH}_{3}$ emissions (Hernández et al., 2011). Additionally, emission measurement studies show that animal category (e.g., gilts, barrows, boars, etc.) could also have an impact on the level of $\mathrm{NH}_{3}$ reductions that can be achieved with reduced CP in pigs (Lynch et al., 2007, 2008). This suggests that even though reducing $\mathrm{CP}$ in animal diets is an effective $\mathrm{NH}_{3}$ abatement option, influencing factors such as level of CP reductions, feed composition, animal type, growth stage, and animal category must be accounted for while estimating emission reductions (Sajeev et al., 2017). Improved classification and reporting of influencing factors are necessary to ensure that the proposed emission reductions can be achieved. The supplemental section in the UNECE guidance document on $\mathrm{NH}_{3}$ abatement strives toward this objective by accounting for and categorizing the effect of influencing factors on $\mathrm{NH}_{3}$ emissions from a reduction in CP levels (Bittman et al., 2014).
Another example is related to the acidification of manure and its impact on $\mathrm{N}_{2} \mathrm{O}$ emissions. The results show that lactic acid reduced $\mathrm{N}_{2} \mathrm{O}$ emissions by $93 \pm 3 \%$, whereas the addition of sulfuric acid had lower $\mathrm{N}_{2} \mathrm{O}$ reductions of $17 \pm 30 \%$. Nitric acid, on the other hand, led to a significant increase in $\mathrm{N}_{2} \mathrm{O}$ emissions (>100\%) (Berg et al., 2006b; Petersen et al., 2012; Owusu-Twum et al., 2017). Although nitric acid is currently not used as an abatement option, it does reduce $\mathrm{NH}_{3}$ and $\mathrm{CH}_{4}$ emissions. This underlines the implication of different acid choices on emission reduction trends. Clearly specifying the choice of acid to be added can improve the effectiveness of acidification as an abatement option.

Similarly, overall estimates suggest that the use of covers during manure storage led to an increase in $\mathrm{N}_{2} \mathrm{O}$ emissions. However, on assessing the effects of different types of covers on $\mathrm{N}_{2} \mathrm{O}$ emissions, the addition of chopped straw and formation of natural crusts were two options that significantly increased $\mathrm{N}_{2} \mathrm{O}$ emissions (>500\%). Other covering options such as wooden lids, plastic sheets, and floating films were successful in reducing $\mathrm{N}_{2} \mathrm{O}$ emissions in the range of $30 \%$. Clustering these different covering materials together without understanding the differences in the way they operate can severely undercut potential emission reductions and make the whole option unviable. The observations and insights discussed above call for researchers to perform experiments where emission reductions from different abatement options are compared, along with explicitly describing assumptions, reporting influencing factors, highlighting caveats, and properly classifying the results associated with the abatement options they analyze and recommend. This will help to correctly understand the dynamics of implementing an abatement option, ensuring desired efficiency.

\section{Accounting for Emission Interactions}

Our results also highlight and quantify the extent of interactions between the three gases along the manure management chain for different stages and for various abatement options. Current policies on manure management adopt a uniform approach that is limited to a single pollutant to abate either air pollution from increased $\mathrm{NH}_{3}$ emissions or climate change impacts due to GHGs. Given the extent of interactions between multiple pollutants such one-dimensional policy initiatives may prove to be suboptimal. The results presented here indicate that although a particular abatement option is effective in reducing emissions of a single gas, it might not be as effective for other gases and may even lead to an increase in emissions. This was evident in various stages of the manure management chain. In the case of housing, the use of air scrubbers was promising when it comes to $\mathrm{NH}_{3}$ emissions. However, the use of biological scrubbers could lead to an increase in $\mathrm{N}_{2} \mathrm{O}$ emissions (>100\%). Similarly, in the case of manure storage, the use of chopped straw and formation of surface crust were effective $\mathrm{NH}_{3}$ abatement options, with reduction estimates of 66 and $57 \%$, respectively. However, these options showed a significant increase in $\mathrm{N}_{2} \mathrm{O}$ emissions (>500\%) and a negligible to moderate abatement (12\%) of $\mathrm{CH}_{4}$ emissions.

Another example where the effects of interactions were visible was during the application of manure to soils. Although shallow injection was capable of reducing $\mathrm{NH}_{3}$ emissions by $71 \%$, it can lead to increases in $\mathrm{N}_{2} \mathrm{O}$ emissions (>200\%) relative to surface 


\section{Need for Comprehensive Emission Measurements}

Some studies have estimated the implications of abatement options on emission reductions for the whole manure management chain (Hou et al., 2015, 2017; Wang et al., 2017). These studies are useful in charting out abatement pathways that optimize both $\mathrm{NH}_{3}$ and GHG emissions for the whole chain. In this study, however, we avoid these types of estimations due to the following reasons. First, the emission reduction estimates reported in this study, aggregated from a multitude of existing studies, are mostly limited to a single manure management stage. Thus, the specific effects of an abatement option on other manure management stages were not fully clear. For example, although frequent removal of manure from animal housing is a promising abatement option that reduces all three gases at the housing level, the removed manure must be handled properly down the whole manure management chain to prevent elevated emissions at later stages. Assessments that track the fate of manure through all stages would offer more realistic emission estimates, as opposed to emission trends accumulated from individual studies. Second, only a few studies among the many considered here measured the effect of an abatement option on all three gases simultaneously. Such studies are important in reducing variability in emission estimates, since the assumptions and site-specific conditions would be the same. In contrast, populating emission estimates from multiple studies with varying experimental conditions could increase variability. For example, with some abatement options, such as reduced CP content in animal diets, feed additives, air scrubbers, or acidification, research has nearly exclusively focused on $\mathrm{NH}_{3}$ emissions. The impact of these measures on GHG emissions must be further investigated before an overall impact can be determined. Additional research is also needed to understand the mechanism of emissions under the influence of external factors. This was highlighted during the use of covers where studies show that storage conditions and external factors affect $\mathrm{N}_{2} \mathrm{O}$ emissions (Rodhe et al., 2012; Petersen et al., 2013). Furthermore, combining different abatement options might lead to enhanced emission reductions. For example, combining frequent removal of manure and air scrubbers in housing may further reduce emissions compared with using just a single option. However, measurement studies that combine different abatement options and employ a whole-chain view are rare. These highlighted shortcomings call for comprehensive, reliable, and consistent emission measurement studies that measure the effect of abatement options on all three gases along the manure management chain while allowing for combination of different abatement options. These measurements can then help populate and correctly assess the effectiveness of abatement options for the entire manure management chain.

\section{Conclusions}

This study provides a review of abatement options for both $\mathrm{NH}_{3}$ and $\mathrm{GHG}$ sertaining to the management of liquid manure across different stages. Analysis of the emission reduction estimates highlights the importance of accounting for interactions between emissions. Some abatement options, such as manure acidification, anaerobic digesters, and frequent removal of manure, can reduce both $\mathrm{NH}_{3}$ and GHG emissions, whereas other options are associated with tradeoffs or pollution swapping. The results call for a shift from assessment of single-stage abatement to a whole-chain perspective to ensure overall emission reduction across the entire manure management chain. The analysis also identified some key elements, such as proper clustering, reporting of influencing factors, and explicitly describing assumptions associated with abatement options, which can reduce variability in emission reduction estimates and, in some cases, make previously unviable options applicable. Furthermore, prioritization of abatement options that change manure characteristics throughout the manure management chain (e.g., low-protein diets, anaerobic digestion, or slurry acidification) can help in determining low-risk emission reduction options. Such assessments, supported by reliable and comprehensive emission measurement studies, can help pave the way toward consistent and integrated manure management strategies that reduce the impact of livestock production on both air quality and climate change.

\section{Acknowledgments}

This work was funded by the Austrian Science Fund (FWF) under Research Grant W 1256-G15 (Doctoral Programme Climate ChangeUncertainties, Thresholds and Coping Strategies).

\section{References}

Agle, M., A. Hristov, S. Zaman, C. Schneider, P. Ndegwa, and V. Vaddella. 2010. The effects of ruminally degraded protein on rumen fermentation and ammonia losses from manure in dairy cows. J. Dairy Sci. 93:1625-1637. doi: $10.3168 /$ jds.2009-2579

Amon, B., V. Kryvoruchko, T. Amon, and S. Zechmeister-Boltenstern. 2006. Methane, nitrous oxide and ammonia emissions during storage and after application of dairy cattle slurry and influence of slurry treatment. Agric. Ecosyst. Environ. 112:153-162. doi:10.1016/j.agee.2005.08.030

Amon, B., V. Kryvoruchko, M. Fröhlich, T. Amon, A. Pöllinger, I. Mösenbacher, and A. Hausleitner. 2007. Ammonia and greenhouse gas emissions from a straw flow system for fattening pigs: Housing and manure storage. Livest. Sci. 112:199-207. doi:10.1016/j.livsci.2007.09.003

Amon, B., K. Smith, L. Valli, H. Döhler, M. Hansen, H. Menzi, and S. Wulf. 2014. Manure storage techniques. In: S. Bittman, M. Dedina, C.M. Howard, O. Oenema, and M.A. Sutton, editors, Options for ammonia mitigation: Guidance from the UNECE Task Force on Reactive Nitrogen. Ctr. Ecol. Hydrol., Edinburgh, UK. p. 26-28. http://www.clrtap-tfrn.org/sites/clrtap-tfrn.org/ files/documents/AGD_final_file.pdf (accessed 24 Oct. 2017).

Anthony, S., D. Duethman, R. Gooday, D. Harris, P. Newell-Price, D. Chadwick, and T. Misselbrook. 2008. Quantitative assessment of scenarios for managing trade-off between economics, environment and media. Rep. no. Defra WQ0106 (Module 6). Dep. Environ. Food Rural Affairs, London. http:// sciencesearch.defra.gov.uk/Default.aspx?Menu=Menu\&Module=More\&L ocation $=$ None\&Completed $=0 \&$ ProjectID $=14421($ accessed 24 Oct. 2017$)$.

Berg, W., R. Brunsch, and I. Pazsiczki. 2006a. Greenhouse gas emissions from covered slurry compared with uncovered during storage. Agric. Ecosyst. Environ. 112:129-134. doi:10.1016/j.agee.2005.08.031

Berg, W., M. Türk, and H. Hellebrand. 2006b. Effects of acidifying liquid cattle manure with nitric or lactic acid on gaseous emissions. In: Proceedings of the Workshop on Agricultural Air Quality: State of the Science, Potomac, MD. 4-8 June 2006. North Carolina State Univ., Raleigh, NC. p. 15-17.

Bittman, S., M. Dedina, C. Howard, O. Oenema, and M. Sutton. 2014. Options for ammonia mitigation: Guidance from the UNECE Task Force on Reactive Nitrogen. Ctr. Ecol. Hydrol., Edinburgh, UK. http://www.clrtap-tfrn. org/sites/clrtap-tfrn.org/files/documents/AGD_final_file.pdf (accessed 24 Oct. 2017).

Brink, C., E. van Ierland, L. Hordijk, and C. Kroeze. 2005. Cost-effective emission abatement in agriculture in the presence of interrelations: Cases for the Netherlands and Europe. Ecol. Econ. 53:59-74. doi:10.1016/j. ecolecon.2004.05.008

Chadwick, D., S. Sommer, R. Thorman, D. Fangueiro, L. Cardenas, B. Amon, and T. Misselbrook. 2011. Manure management: Implications for greenhouse gas emissions. Anim. Feed Sci. Technol. 166-167:514-531. doi:10.1016/j.anifeedsci.2011.04.036

Chantigny, M.H., D.A. Angers, P. Rochette, G. Bélanger, D. Massé, and D. Côté. 2007. Gaseous nitrogen emissions and forage nitrogen uptake on soils fertilized with raw and treated swine manure. J. Environ. Qual. 36:18641872. doi: $10.2134 /$ jeq2007.0083 
Chantigny, M.H., J.D. MacDonald, C. Beaupré, P. Rochette, D.A. Angers, D. Massé, and L.-É. Parent. 2009. Ammonia volatilization following surface application of raw and treated liquid swine manure. Nutr. Cycling Agroecosyst. 85:275-286.

Clemens, J., M. Trimborn, P. Weiland, and B. Amon. 2006. Mitigation of greenhouse gas emissions by anaerobic digestion of cattle slurry. Agric. Ecosyst. Environ. 112:171-177. doi:10.1016/j.agee.2005.08.016

Dai, X.-R., and V. Blanes-Vidal. 2013. Emissions of ammonia, carbon dioxide, and hydrogen sulfide from swine wastewater during and after acidification treatment: Effect of $\mathrm{pH}$, mixing and aeration. J. Environ. Manage. 115:147-154. doi:10.1016/j.jenvman.2012.11.019

De Klein, C., R.S. Novoa, S. Ogle, K.A. Smith, P. Rochette, T.C. Wirth, et al. 2006. $\mathrm{N}_{2} \mathrm{O}$ emissions from managed soils, and $\mathrm{CO}_{2}$ emissions from lime and urea application. In: S. Eggleston, L. Buendia, K. Miwa, T. Ngara, K. Tanabe, editors, 2006 IPCC guidelines for national greenhouse gas inventories. Vol. 4: Agriculture, forestry and other land use. National Greenhouse Gas Inventories Programme, Institute for Global Environmental Studies, Kamiyamaguchi, Hayama, Kanagawa, Japan. p. 1-54. http:// www.ipcc-nggip.iges.or.jp/public/2006gl/pdf/4_Volume4/V4_11_ Ch11_N2O\&CO2.pdf (accessed 24 Oct. 2017).

De Vries, J., W. Hoogmoed, C. Groenestein, J. Schröder, W. Sukkel, I. De Boer, and P.G. Koerkamp. 2015. Integrated manure management to reduce environmental impact: I. Structured design of strategies. Agric. Syst. 139:2937. doi:10.1016/j.agsy.2015.05.010

Del Prado, A., P. Crosson, J.E. Olesen, and C. Rotz. 2013. Whole-farm models to quantify greenhouse gas emissions and their potential use for linking climate change mitigation and adaptation in temperate grassland ruminant-based farming systems. Animal 7:373-385. doi:10.1017/ S1751731113000748

Dell, C.J., J.J. Meisinger, and D.B. Beegle. 2011. Subsurface application of manures slurries for conservation tillage and pasture soils and their impact on the nitrogen balance. J. Environ. Qual. 40:352-361. doi:10.2134/jeq2010.0069

Duncan, E., C. Dell, P. Kleinman, and D. Beegle. 2017. Nitrous oxide and ammonia emissions from injected and broadcast-applied dairy slurry. J. Environ. Qual. 46:36-44. doi:10.2134/jeq2016.05.0171

Fangueiro, D., M. Hjorth, and F. Gioelli. 2015. Acidification of animal slurry-A review. J. Environ. Manage. 149:46-56. doi:10.1016/j. jenvman.2014.10.001

Feilberg, A., and S.G. Sommer. 2013. Ammonia and malodorous gases: Sources and abatement technologies. In: S.G. Sommer, M.L. Christensen, T. Schmidt, and L.S. Jensen, editors, Animal manure recycling: Treatment and management. John Wiley \& Sons, Chichester, UK. p. 153-175.

Galassi, G., S. Colombini, L. Malagutti, G. Crovetto, and L. Rapetti. 2010. Effects of high fibre and low protein diets on performance, digestibility, nitrogen excretion and ammonia emission in the heavy pig. Anim. Feed Sci. Technol. 161:140-148. doi:10.1016/j.anifeedsci.2010.08.009

Gooday, R., S. Anthony, D. Chadwick, P. Newell-Price, D. Harris, D. Duethmann, et al. 2014. Modelling the cost-effectiveness of mitigation methods for multiple pollutants at farm scale. Sci. Total Environ. 468-469:11981209. doi:10.1016/j.scitotenv.2013.04.078

Goulding, K., T. Willison, C. Webster, and D. Powlson. 1996. Methane fluxes in aerobic soils. Environ. Monit. Assess. 42:175-187.

Hansen, C.F., G. Sørensen, and M. Lyngbye. 2007. Reduced diet crude protein level, benzoic acid and inulin reduced ammonia, but failed to influence odour emission from finishing pigs. Livest. Sci. 109:228-231. doi:10.1016/j.livsci.2007.01.133

Hansen, R.R., D.A. Nielsen, A. Schramm, L.P. Nielsen, N.P. Revsbech, and M.N Hansen. 2009. Greenhouse gas microbiology in wet and dry straw crust covering pig slurry. J. Environ. Qual. 38:1311-1319. doi:10.2134/jeq2008.0336

Hernández, F., S. Martínez, C. López, M. Megías, M. López, and J. Madrid. 2011. Effect of dietary crude protein levels in a commercial range, on the nitrogen balance, ammonia emission and pollutant characteristics of slurry in fattening pigs. Animal 5:1290-1298. doi:10.1017/S1751731111000115

Hou, Y., G.L. Velthof, J.P. Lesschen, I.G. Staritsky, and O. Oenema. 2017. Nutrient recovery and emissions of ammonia, nitrous oxide and methane from animal manure in Europe: Effects of manure treatment technologies. Environ. Sci. Technol. 51:375-383. doi:10.1021/acs.est.6b04524

Hou, Y., G.L. Velthof, and O. Oenema. 2015. Mitigation of ammonia, nitrous oxide and methane emissions from manure management chains: A meta-analysis and integrated assessment. Glob. Change Biol. 21:1293-1312.

Hristov, A., J. Oh, C. Lee, R. Meinen, F. Montes, T. Ott, et al. 2013. Mitigation of greenhouse gas emissions in livestock production: A review of technical options for non- $\mathrm{CO}_{2}$ emissions. Anim. Prod. Health Paper 177. FAO, Rome. http://www.fao.org/docrep/018/i3288e/i3288e00.htm (accessed 24 Oct. 2017).
Huijsmans, J., J. Hol, and G. Vermeulen. 2003. Effect of application method, manure characteristics, weather and field conditions on ammonia volatilization from manure applied to arable land. Atmos. Environ. 37:3669-3680. doi:10.1016/S1352-2310(03)00450-3

Ivanova-Peneva, S.G., A.J. Aarnink, and M.W. Verstegen. 2008. Ammonia emissions from organic housing systems with fattening pigs. Biosystems Eng. 99:412-422. doi:10.1016/j.biosystemseng.2007.11.006

Jensen, A. 2002. Changing the environment in swine buildings using sulfuric acid. Trans. ASAE 45:223-227. doi:10.13031/2013.7874

Kai, P., P. Pedersen, J. Jensen, M.N. Hansen, and S.G. Sommer. 2008. A wholefarm assessment of the efficacy of slurry acidification in reducing ammonia emissions. Eur. J. Agron. 28:148-154. doi:10.1016/j.eja.2007.06.004

Külling, D., H. Menzi, T. Kröber, A. Neftel, F. Sutter, P. Lischer, and M. Kreuzer. 2001. Emissions of ammonia, nitrous oxide and methane from different types of dairy manure during storage as affected by dietary protein content. J. Agric. Sci. 137:235-250. doi:10.1017/S0021859601001186

Külling, D., H. Menzi, F. Sutter, P. Lischer, and M. Kreuzer. 2003. Ammonia, nitrous oxide and methane emissions from differently stored dairy manure derived from grass-and hay-based rations. Nutr. Cycling Agroecosyst. 65:13-22. doi:10.1023/A:1021857122265

Le, P., A. Aarnink, and A. Jongbloed. 2009. Odour and ammonia emission from pig manure as affected by dietary crude protein level. Livest. Sci. 121:267274. doi:10.1016/j.livsci.2008.06.021

Lee, C., A. Hristov, C. Dell, G. Feyereisen, J. Kaye, and D. Beegle. 2012. Effect of dietary protein concentration on ammonia and greenhouse gas emitting potential of dairy manure. J. Dairy Sci. 95:1930-1941. doi:10.3168/jds.2010-4141

Lynch, M., C. O'Shea, T. Sweeney, J. Callan, and J. O'Doherty. 2008. Effect of crude protein concentration and sugar-beet pulp on nutrient digestibility, nitrogen excretion, intestinal fermentation and manure ammonia and odour emissions from finisher pigs. Animal 3:425-434.

Lynch, M., T. Sweeney, J. Callan, B. Flynn, and J. O'Doherty. 2007. The effect of high and low dietary crude protein and inulin supplementation on nutrient digestibility, nitrogen excretion, intestinal microflora and manure ammonia emissions from finisher pigs. Animal 8:1112-1121.

Madrid, J., S. Martínez, C. López, J. Orengo, M. López, and F. Hernández. 2013. Effects of low protein diets on growth performance, carcass traits and ammonia emission of barrows and gilts. Anim. Prod. Sci. 53:146-153. doi:10.1071/AN12067

Martens, W., M. Martinec, R. Zapirain, M. Stark, E. Hartung, and U. Palmgren. 2001. Reduction potential of microbial, odour and ammonia emissions from a pig facility by biofilters. Int. J. Hyg. Environ. Health 203:335-345. doi:10.1078/1438-4639-00035

Massé, D., G. Talbot, and Y. Gilbert. 2011. On farm biogas production: A method to reduce GHG emissions and develop more sustainable livestock operations. Anim. Feed Sci. Technol. 166-167:436-445. doi:10.1016/j. anifeedsci.2011.04.075

Melse, R.W., and J. Mosquera. 2014. Nitrous oxide $\left(\mathrm{N}_{2} \mathrm{O}\right)$ emissions from biotrickling filters used for ammonia removal at livestock facilities. Water Sci. Technol. 69:994-1003. doi:10.2166/wst.2013.826

Montalvo, G., J. Morales, C. Pineiro, S. Godbout, and M. Bigeriego. 2013. Effect of different dietary strategies on gas emissions and growth performance in post-weaned piglets. Span. J. Agric. Res. 11:1016-1027. doi:10.5424/ sjar/2013114-3185

Montes, F., R. Meinen, C. Dell, A. Rotz, A. Hristov, J. Oh, et al. 2013. SPECIAL TOPICS: Mitigation of methane and nitrous oxide emissions from animal operations: II. A review of manure management mitigation options. J. Anim. Sci. 91:5070-5094. doi:10.2527/jas.2013-6584

Nyord, T., M. Hansen, and T. Birkmose. 2012. Ammonia volatilisation and crop yield following land application of solid-liquid separated, anaerobically digested, and soil injected animal slurry to winter wheat. Agric. Ecosyst. Environ. 160:75-81. doi:10.1016/j.agee.2012.01.002

O'Connell, J., J. Callan, and J. O'Doherty. 2006. The effect of dietary crude protein level, cereal type and exogenous enzyme supplementation on nutrient digestibility, nitrogen excretion, faecal volatile fatty acid concentration and ammonia emissions from pigs. Anim. Feed Sci. Technol. 127:73-88. doi:10.1016/j.anifeedsci.2005.09.002

Oenema, O., S. Tamminga, H. Menzi, A. Aarnik, and C. Pineiro. 2014. Livestock feeding strategies. In: S. Bittman, M. Dedina, C.M. Howard, O. Oenema, and M.A. Suttion, editors, Options for ammonia mitigation: Guidance from the UNECE Task Force on Reactive Nitrogen. Ctr. Ecol. Hydrol., Edinburgh, UK. p. 10-13, http://www.clrtap-tfrn.org/sites/clrtap-tfrn. org/files/documents/AGD_final_file.pdf (accessed on 24 Oct. 2017).

Oenema, O., H. Witzke, Z. Klimont, J. Lesschen, and G. Velthof. 2009. Integrated assessment of promising measures to decrease nitrogen losses from agriculture in EU-27. Agric. Ecosyst. Environ. 133:280-288. doi:10.1016/j. agee.2009.04.025 
Owusu-Twum, M., N. Loick, L. Cardenas, J. Coutinho, H. Trindade, and D. Fangueiro. 2017. Nitrogen dynamics in soils amended with slurry treated by acid or DMPP addition. Biol. Fertil. Soils 53:339-347. doi:10.1007/ s00374-017-1178-0

Panetta, D., W.J. Powers, H. Xin, B.J. Kerr, and K.J. Stalder. 2006. Nitrogen excretion and ammonia emissions from pigs fed modified diets. J. Environ. Qual. 35:1297-1308. doi:10.2134/jeq2005.0411

Petersen, S.O., A.J. Andersen, and J. Eriksen. 2012. Effects of cattle slurry acidification on ammonia and methane evolution during storage. J. Environ. Qual. 41:88-94. doi:10.2134/jeq2011.0184

Petersen, S.O., N. Dorno, S. Lindholst, A. Feilberg, and J. Eriksen. 2013. Emissions of $\mathrm{CH}_{4}, \mathrm{~N}_{2} \mathrm{O}, \mathrm{NH}_{3}$ and odorants from pig slurry during winter and summer storage. Nutr. Cycling Agroecosyst. 95:103-113.

Petersen, S.O., O. Højberg, M. Poulsen, C. Schwab, and J. Eriksen. 2014. Methanogenic community changes, and emissions of methane and other gases, during storage of acidified and untreated pig slurry. J. Appl. Microbiol. 117:160-172. doi:10.1111/jam.12498

Petersen, S.O., and S.G. Sommer. 2011. Ammonia and nitrous oxide interactions: Roles of manure organic matter management. Anim. Feed Sci. Technol. 166-167:503-513. doi:10.1016/j.anifeedsci.2011.04.077

Portejoie, S., J. Dourmad, J. Martinez, and Y. Lebreton. 2004. Effect of lowering dietary crude protein on nitrogen excretion, manure composition and ammonia emission from fattening pigs. Livest. Prod. Sci. 91:45-55. doi:10.1016/j.livprodsci.2004.06.013

Rodhe, L.K., J. Abubaker, J. Ascue, M. Pell, and Å. Nordberg. 2012. Greenhouse gas emissions from pig slurry during storage and after field application in northern European conditions. Biosystems Eng. 113:379-394. doi:10.1016/j.biosystemseng.2012.09.010

Roos, K., J.B. Martin, Jr., and M. Moser. 2004. A manual for developing biogas systems at commercial farms in the United States: AgSTAR handbook. 2nd ed. USEPA. Washington, DC. https://www.epa.gov/sites/production/files/2014-12/documents/agstar-handbook.pdf (accessed 24 Oct. 2017).

Sajeev, E.P.M., B. Amon, C. Ammon, W. Zollitsch, and W. Winiwarter. 2017. Evaluating the potential of dietary crude protein manipulation in reducing ammonia emissions from cattle and pig manure: A meta-analysis. Nutr. Cycling Agroecosyst. doi:10.1007/s10705-017-9893-3

Sherlock, R.R., S.G. Sommer, R.Z. Khan, C. Wood, E.A. Guertal, J.R. Freney, et al. 2002. Ammonia, methane, and nitrous oxide emission from pig slurry applied to a pasture in New Zealand. J. Environ. Qual. 31:1491-1501. doi: $10.2134 /$ jeq2002.1491

Sistani, K., J. Warren, N. Lovanh, S. Higgins, and S. Shearer. 2010. Greenhouse gas emissions from swine effluent applied to soil by different methods. Soil Sci. Soc. Am. J. 74:429-435. doi:10.2136/sssaj2009.0076

Sommer, S.G., J.E. Olesen, S.O. Petersen, M.R. Weisbjerg, L. Valli, L. Rodhe, and F. Béline. 2009. Region-specific assessment of greenhouse gas mitigation with different manure management strategies in four agroecological zones. Glob. Change Biol. 15:2825-2837.

Steinfeld, H., P. Gerber, T. Wassenaar, V. Castel, M. Rosales, and C. de Haan. 2007. Livestock's long shadow. Environmental issues and options. Steering Comm. Livestock, Environ. Dev. Initiative, FAO, Rome. http:// www.fao.org/docrep/010/a0701e/a0701e00.HTM (accessed on 24 Oct. 2017).

Stocker, T., D. Qin, and G.-K. Plattner. 2013. Technical summary. In: T. Stocker, D. Qin, G-K. Plattner, editors, Climate change 2013: The physical science basis. Contribution of Working Group I to the Fifth Assessment Report of the Intergovernmental Panel on Climate Change. Cambridge Univ. Press, Cambridge, UK. p. 33-115. http://www.ipcc.ch/report/ar5/wg1/ (accessed on 24 Oct. 2017).

Sutton, M.A., C.M. Howard, J.W. Erisman, G. Billen, A. Bleeker, P. Grennfelt, et al. 2011. The European nitrogen assessment: Sources, effects and policy perspectives. Cambridge Univ. Press, Cambridge, UK. p. 9-32.
Thomsen, I.K., A.R. Pedersen, T. Nyord, and S.O. Petersen. 2010. Effects of slurry pre-treatment and application technique on short-term $\mathrm{N}_{2} \mathrm{O}$ emissions as determined by a new non-linear approach. Agric. Ecosyst. Environ. 136:227-235. doi:10.1016/j.agee.2009.12.001

UNECE. 2015. Methane and ammonia air pollution. Policy brief prepared by the UNECE Task Force on Reactive Nitrogen. Task Force React. Nitrogen, Working Group Strat. Rev. of the UNECE Convention on Long-Range Transboundary Air Pollut., Aarhus, Denmark. http://www.clrtap-tfrn.org/ content/methane-and-ammonia-air-pollution (accessed on 24 Oct. 2017).

UNECE. 2016. Convention of long-range transboundary atmospheric pollution. United Nations Econ. Commun. Europe, Geneva. http://ec.europa.eu/eurostat/web/environment/air-emissions-inventories/database (accessed 24 Oct. 2017).

UNFCCC. 2016. Common reporting format (CRF) tables and national inventory reports (NIRs). United Nations Framework Convention on Clim. Change, Bonn, Germany. http://di.unfccc.int/ghg_profile_annex1 (accessed 25 Apr. 2017)

Vallejo, A., L. García-Torres, J.A. Díez, A. Arce, and S. López-Fernández. 2005. Comparison of $\mathrm{N}$ losses $\left(\mathrm{NO}_{3}^{-}, \mathrm{N}_{2} \mathrm{O}, \mathrm{NO}\right)$ from surface applied, injected or amended (DCD) pig slurry of an irrigated soil in a Mediterranean climate. Plant Soil 272:313-325. doi:10.1007/s11104-004-5754-3

Van der Heyden, C., P. Demeyer, and E.I. Volcke. 2015. Mitigating emissions from pig and poultry housing facilities through air scrubbers and biofilters: State-of-the-art and perspectives. Biosystems Eng. 134:74-93. doi:10.1016/j.biosystemseng.2015.04.002

VanderZaag, A., R. Gordon, R. Jamieson, D. Burton, and G. Stratton. 2009. Gas emissions from straw covered liquid dairy manure during summer storage and autumn agitation. Trans. ASABE 52:599-608. doi: $10.13031 / 2013.26832$

Wagner, F., W. Winiwarter, Z. Klimont, M. Amann, and M. Sutton. 2011. Ammonia reductions and costs implied by the three ambition levels proposed in the Draft Annex IX to the Gothenburg protocol. CIAM Rep. 5. Ctr. Integ. Assessment Modelling, Int. Inst. Appl. Syst. Anal., Laxenburg, Austria. http://www.iiasa.ac.at/web/home/research/researchPrograms/air/ MAG-CIAM5.pdf (accessed 24 Oct. 2017).

Wagner, S., E. Angenendt, O. Beletskaya, and J. Zeddies. 2015. Costs and benefits of ammonia and particulate matter abatement in German agriculture including interactions with greenhouse gas emissions. Agric. Syst. 141:5868. doi:10.1016/j.agsy.2015.09.003

Walsh, J.J., D.L. Jones, G. Edwards-Jones, and A.P. Williams. 2012. Replacing inorganic fertilizer with anaerobic digestate may maintain agricultural productivity at less environmental cost. J. Plant Nutr. Soil Sci. 175:840-845. doi: $10.1002 /$ jpln.201200214

Wang, K., D. Huang, H. Ying, and H. Luo. 2014a. Effects of acidification during storage on emissions of methane, ammonia, and hydrogen sulfide from digested pig slurry. Biosystems Eng. 122:23-30. doi:10.1016/j. biosystemseng.2014.03.002

Wang, Y., H. Dong, Z. Zhu, P.J. Gerber, H. Xin, P. Smith, et al. 2017. Mitigating greenhouse gas and ammonia emissions from swine manure management: A system analysis. Environ. Sci. Technol. 51:4503-4511. doi:10.1021/acs. est.6b06430

Wang, Y., H. Dong, Z. Zhu, C. Liu, and H. Xin. 2014b. Comparison of air emissions from raw liquid pig manure and biogas digester effluent storages. Trans. ASABE 57:635-645.

Webb, J., B. Pain, S. Bittman, and J. Morgan. 2010. The impacts of manure application methods on emissions of ammonia, nitrous oxide and on crop response-A review. Agric. Ecosyst. Environ. 137:39-46. doi:10.1016/j. agee.2010.01.001

Winiwarter, W., and Z. Klimont. 2011. The role of N-gases $\left(\mathrm{N}_{2} \mathrm{O}, \mathrm{NO}_{x}, \mathrm{NH}_{3}\right)$ in cost-effective strategies to reduce greenhouse gas emissions and air pollution in Europe. Curr. Opin. Environ. Sustain. 3:438-445. doi:10.1016/j. cosust.2011.08.003 